\title{
POTENSI PENGHASILAN BAJA DARI MEDIA CENDAWAN TAMAT TEMPOH YANG DIPROSES SEMULA BAGI TANAMAN POKOK BENDI
}

\author{
MAT ZUKI BIN ABDUL RAHMAN* \\ AHMAD FARUDZI BIN AZIB** \\ KAMARUZAMAN BIN ABDULLAH***
}

\begin{abstract}
Abstrak
Artikel ini membincangkan tentang penghasilan baja kompos dari media cendawan yang telah tamat tempoh bagi tanaman pokok bendi. Terdapat dua jenis sampel baja yang digunakan dalam kajian ini iaitu baja kimia dan juga organik (baja dari media cendawan tamat tempoh). Ketinggian pokok dan lebar daun diukur sebagai parameter ujikaji. Kajian ini melibatkan penggunaan media cendawan yang telah tamat tempoh kerana ia mengandungi unsur fosforus dan kalium yang tinggi dicampur dengan bahan campuran. Unsur ini baik untuk pertumbuhan akar dan kesuburan pokok. Pokok bendi dipilih sebagai pokok ujikaji memandangkan ianya merupakan pokok yang mudah ditanam. Hasil ujikaji menunjukkan ketinggian pokok dan kelebaran daun daripada baja kajian menunjukkan peningkatan tumbesaran hampir sama dengan pokok bendi yang menggunakan baja kimia.
\end{abstract}

Kata Kunci: Baja, Media Cendawan Tamat Tempoh, Bendi 


\begin{abstract}
Composting of media mushrooms that have expired is conducted for the study of fertility of okra plants. There are two types of manure samples used in this study which are divided into chemical and organic fertilizer (manure from expired media mushrooms). Tree height and leaf width are measured as experimental parameters. This study involves the use of media mushroom that has expired because it contains elements of phosphorus and high potassium together with other mixtures. These elements are essential for root growth and plant fertility. Okra tree is selected as experimental subject as the tree is easily grown. The experimental results indicate the height of the tree and width of the leaves planted using experimental manure and it shows an increase in growth that is very similar to okra plants that use chemical fertilizers.
\end{abstract}

Keywords: Fertility, Expired Media Mushroom, Okra 


\subsection{Pengenalan}

Baja kompos merupakan baja yang terhasil apabila bahan organik mereput dan terurai kepada bahan yang kaya dengan nutrien yang dipanggil 'humus' melalui haba dan respirasi yang dilakukan oleh organisma tanah seperti bakteria, cacing dan kulat (Tarmizi, 2005). Bahan yang boleh dijadikan baja kompos amat mudah diperoleh di kawasan sekeliling kita seperti bahan yang kaya dengan nitrogen dan karbon, kulit buah-buahan, sayur-sayuran, daun kering, najis haiwan, sisa makanan dan sebagainya. Walau bagaimanapun, hasil dari pemerhatian, penggunaan baja kompos di dalam bidang pertanian pada masa kini masih lagi pada tahap skala kecil. Ini kerana mereka beranggapan nutrien yang dibekalkan baja kompos tidak setanding dengan baja kimia. Umumnya ramai yang tidak mengetahui bahawa media cendawan yang terlalu tua dan tidak aktif untuk mengeluarkan hasil boleh dijadikan baja kompos,(Redzuan, 2006).

Di dalam kajian ini, pokok bendi telah dipilih sebagai pokok kajian kerana ianya merupakan pokok sayuran yang mudah ditanam. Kajian baja baru perlu dilakukan untuk mengurangkan jumlah buangan media cendawan tamat tempoh. Selain itu juga, kajian ini bertujuan untuk menghasilkan baja yang hanya memerlukan kos yang rendah dan untuk menghasilkan baja yang mesra alam. Kajian ini bertujuan untuk menghasilkan baja yang hanya memerlukan kos yang rendah dan untuk menghasilkan baja yang mesra alam.

\subsection{Penyataan Masalah}

i. Media cendawan yang telah beberapa kali pengunaan tidak dapat digunakan lagi.

ii. Kos bagi baja pertanian yang berasaskan kimia berlipat kali ganda mahalnya

iii. Penggunaan baja pertanian yang berasaskan kimia menjejaskan tahap kesihatan. 


\subsection{Objektif Kajian}

Objektif kajian ini adalah untuk mengenalpasti secara khusus perkara berikut:

i. Mengkaji kadar kesuburan pokok bendi dengan menggunakan baja dari media cendawan yang diproses semula.

ii. Menghasilkan baja berkualiti yang hanya memerlukan kos yang rendah.

iii. Menghasilkan baja yang mesra alam serta meningkatkan tahap kesihatan.

\subsection{Kajian Literatur}

Baja kompos mempunyai peranan yang penting bagi tanah, ia berupaya meningkatkan dan mempertahankan kesuburan sifat kimia, fizik dan biologi dalam tanah tersebut. Baja kompos juga dapat memperbaiki struktur dan lapisan tanah (Nurliyana, 2007).

Bendi, kacang lendir atau kacang bendir atau Okra (Hisbiscus esculentus) merupakan sejenis buah yang dimakan sebagai sayuran yang banyak ditanam di negara-negara ASEAN yang beriklim panas lembap. Bendi yang ada di Malaysia kini dipercayai berasal dari Afrika Tengah dan banyak di tanam di negeri Johor, Perak, Kelantan serta Pulau Pinang. Bendi banyak terjual di pasar-pasar termasuk pasar tani, dan pasar sayur. la berasal dari sebuah tempat yang kini termasuk dalam Habsyah. Sebelum ini, bendi dikelaskan dalam genus Hibiscus, tapi kini telah ditukar kepada Abelmoschus. Bendi sesuai ditanam sebagai komoditi komersial dan tanaman keliling rumah dalam pasu atau polibeg sebagai satu program Bumi Hijau (Mardi, 2002)

Bendi dipercayai berasal dari kawasan Asia Tenggara dan telah ditanam merata dunia termasuk Afrika, India dan Brazil. Kebanyakan bendi diguna segar sebagai sayuran (segar mentah, rebus atau goreng) dan dibuat jeruk. Biji bendi boleh di buat serbuk kopi sementara daunnya untuk makanan ruminan dan batangnya diproses jadi serat (Jab Pertanian Malaysia, 2006)

Pokok bendi adalah dari spesis pokok bunga raya dan pokok kapas dan merupakan tanaman jangka pendek yang boleh menjadi tanaman tahunan. Pokoknya mampu hidup sehingga ketinggian melebihi 2 meter jika dibiarkan. Daunnya berbentuk palmenate yang ada jejari serta mempunyai permukaan yang agak kasar. Batangnya agak lembut ketika muda dan keras sederhana keras. Bunga bendi berwarna kuning dengan ukuran $4-8 \mathrm{~cm}$ garis pusat. Pendebungaan dilaksanakan oleh serangga seperti lebah, rama-rama, kumbang, semut dan sebagainya.(http://pertanianmjg.perak.gov.my/ bahasa/panduan.html). 


\subsection{Metodologi Kajian}

Rekabentuk kajian melibatkan penyedian baja kompos dari media cendawan yang tamat tempoh untuk tanaman bendi, penyediaan kawasan penanaman bendi, semaian benih dan mengkaji tahap kesuburan pokok.

\subsection{Penyediaan Baja Media Cendawan}

Di dalam kajian ini, kami telah menggunakan beberapa bahan campuran untuk meningkatkan kadar khasiat yang perlu ada pada baja yang dikaji. Antara bahan-bahan yang digunakan ialah media cendawan yang telah tamat tempoh, kandungan media cendawan ini ialah habuk kayu getah, dedak halus dan kapur pertanian (Rujuk Rajah 1). Media cendawan yang telah tamat tempoh ini juga mempunyai unsur fosforus dan kalium yang tinggi. Unsur ini baik untuk pertumbuhan akar dan kesuburan pokok. Beberapa bahan dicampur untuk memproses media cendawan tamat tempoh untuk dijadikan baja dengan mencampurkan dengan dedak halus, Campuran dedak halus adalah bertujuan untuk meningkatkan kadar pemakanan pada baja tersebut, tanah lapisan atas (top soil), IMO 4 (bergantung kepada dedak yang digunakan), Fermentation Plant Juice (FPJ), Fish Amino Asid (FAA), FPJ dan FAA perlu dicampurkan terlebih dahulu kedalam air, air yang digunakan untuk campuran ini ialah 10 liter. Campuran tersebut akan digaulkan bersama media cendawan tamat tempoh sehingga mencapai kelembapan media adalah $65 \%$. Setelah mencapai kelembapan yang sesuai campuran ini akan ditutup selama 5 hari untuk menghasil baja. Keberhasilan baja bergantung kepada kepanasan campuran media. 


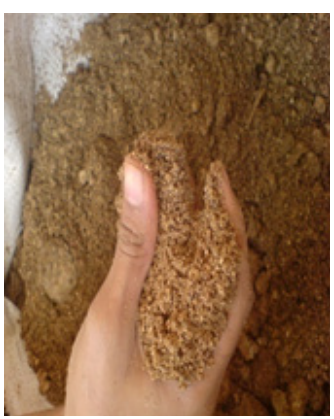

A

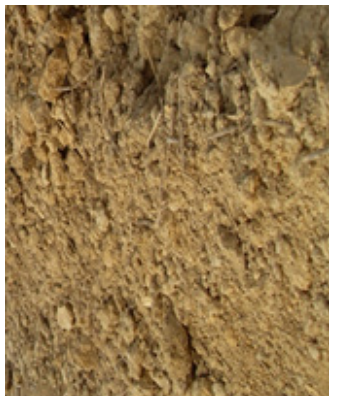

$\mathrm{E}$

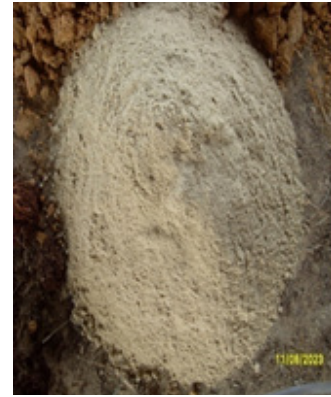

B

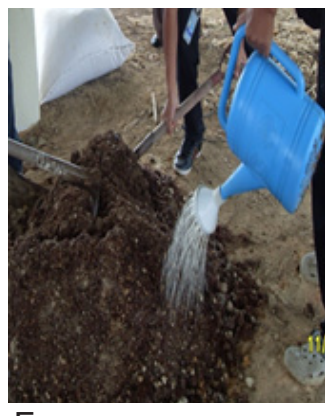

$\mathrm{F}$

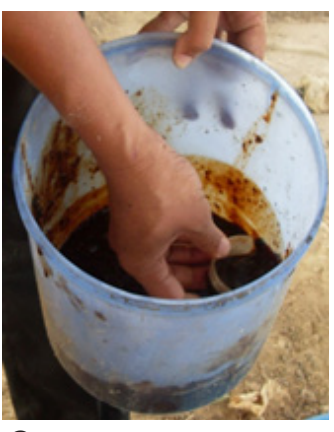

C

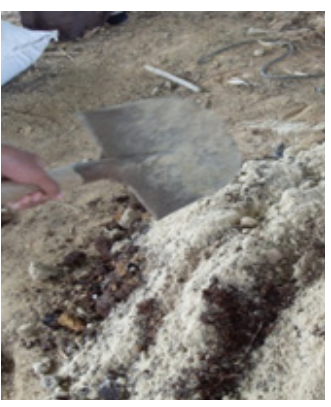

G
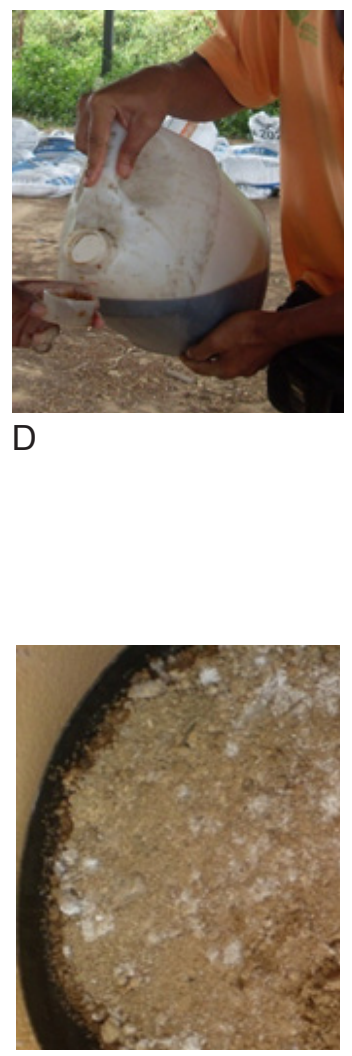

$\mathrm{H}$

Rajah 1: Penyediaan Baja Dari Media Cendawan ; A - Media Cendawan yang tamat tempoh, B - Dedak Halus, C - Fermentation Plant Juice (FPJ), D - Fish Amino Asid (FAA), E - Tanah lapisan atas, F - Air, G - Gaulkan semua bahan, $\mathrm{H}$ - Hasil selepas 5 hari disimpan.

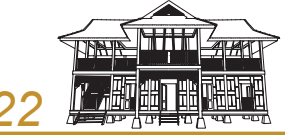

БENIA下 


\subsection{Ujikaji Fizikal}

Ujikaji fizikal adalah merujuk kepada pengukuran pertumbuhan. Pertumbuhan didefinisikan sebagai proses yang bertambah tidak tetap di dalam saiz atau bilangan dalam kajian ini, perubahan dari segi pertumbuhan fizikal ditentukan melalui kaedah pengukuran tumbesarannya. Pokok yang ditanam dalam polibeg akan diukur ketinggian awalnya. Kemudian pemerhatian ketinggian akan dibuat untuk membuat perbandingan perkembangan dan tumbesaran setiap pokok bagi penggunaan dua jenis baja yang berbeza. Ujikaji ini akan dibuat setiap seminggu dua kali.

\subsubsection{Tinggi Pokok}

Dalam ujikaji ini, ketinggian diukur dengan pembaris meter. Untuk mencatat data, aras pokok yang tertinggi diambil kira sebagai ketinggian pokok tersebut, seperti di tunjukkan dalam Rajah 2. Kaedah ini dilakukan ke atas kesemua pokok kajian.

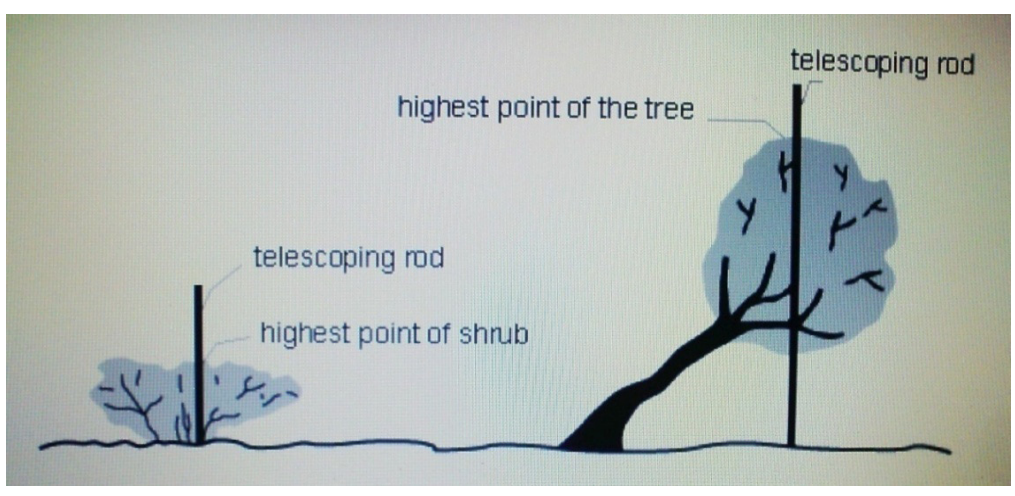

Rajah 2: Kaedah Mengukur Ketinggian Pokok (Mardi, 2002) 


\subsubsection{Lebar daun}

Dalam kajian ini, daun terpilih dilabel dan pengukuran dicatatkan. Untuk mengukur lebar daun, pembaris meter digunakan. Pengukuran dilakukan pada garisan yang diukur seperti dalam Rajah 3.

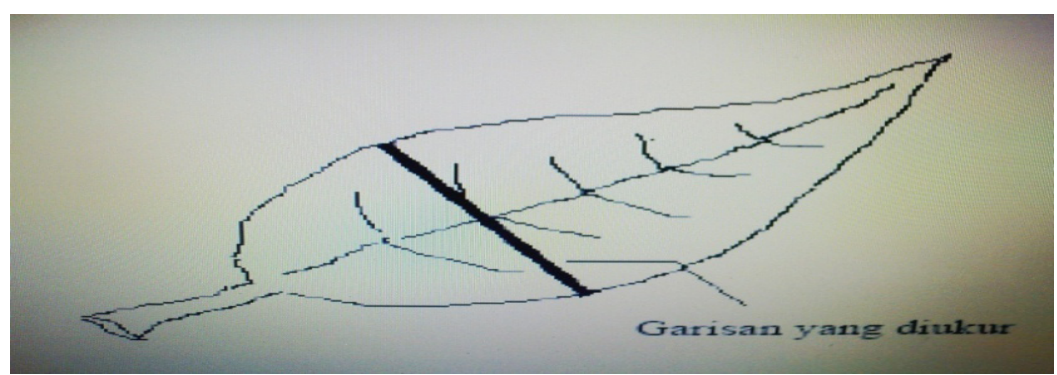

Rajah 3: Kaedah Mengukur Lebar Daun (Mardi, 2002)

\subsection{Dapatan Dan Analisa Projek}

Bagi setiap parameter yang diuji, cerapan dilakukan setiap 1 minggu dan 2 kali bacaan diambil selama tujuh minggu dan bacaan purata akan diambil untuk analisis di akhir ujikaji. Seperti yang sedia maklum dalam bab sebelumnya, ujian dan pemerhatian hanya dijalankan secara fizikal. Rajah 4 menunjukkan kadar pertumbuhan pokok bendi dari minggu 2 hingga minggu 6. 


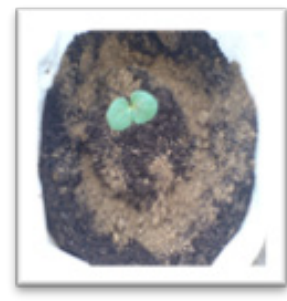

A

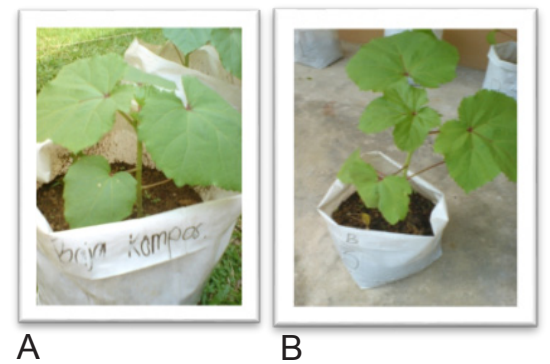

B

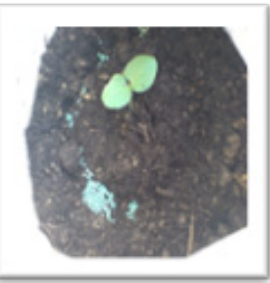

B
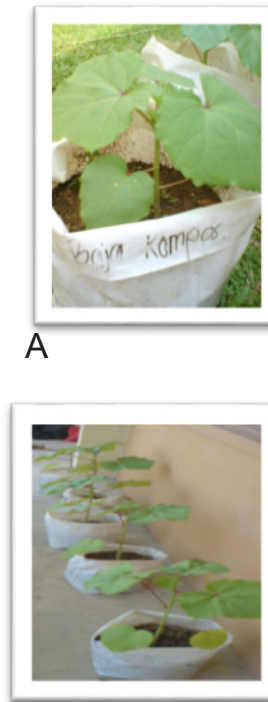

A

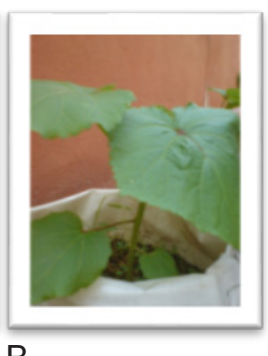

B

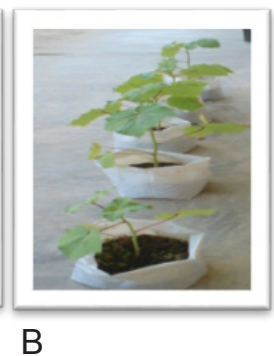

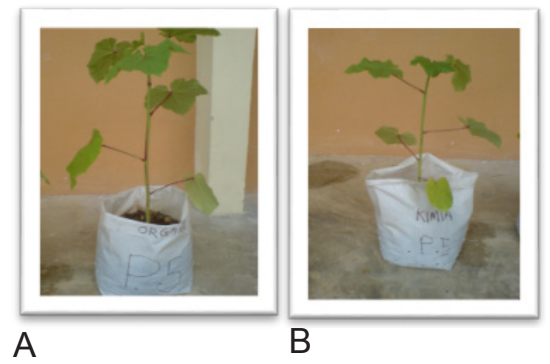

Rajah 4: Kadar Pertumbuhan Pokok Bendi dari Minggu 2 - 6; A - Baja Kajian, B - Baja Kimia 


\subsection{Keputusan Pengukuran Kadar Pertumbuhan (Growth Rate)}

Data yang dipantau selama tujuh minggu terhadap perubahan tinggi pokok dan lebar daun.

\subsubsection{Tinggi Pokok}

Pemerhatian perubahan fizikal tanaman terhadap ketinggian telah dilakukan setiap minggu dan keputusan yang dicatatkan adalah seperti dalam Jadual 1

Jadual 1: Kadar Pertumbuhan Fizikal Tanaman Bendi

\begin{tabular}{|c|c|c|c|c|}
\hline Minggu & Tarikh & Bacaan & Baja kajian & Baja kimia \\
\hline \multirow[b]{2}{*}{1} & \multirow{2}{*}{$11 / 09 / 2011$} & Tinggi (cm) & 4.20 & 4.82 \\
\hline & & Lebar daun (cm) & 2.44 & 2.54 \\
\hline \multirow[b]{2}{*}{2} & \multirow{2}{*}{$18 / 09 / 2011$} & Tinggi (cm) & 6.83 & 6.86 \\
\hline & & Lebar daun (cm) & 3.98 & 3.70 \\
\hline \multirow{2}{*}{3} & \multirow{2}{*}{$25 / 09 / 2011$} & Tinggi (cm) & 14.87 & 14.49 \\
\hline & & Lebar daun (cm) & 11.18 & 9.98 \\
\hline \multirow{2}{*}{4} & \multirow{2}{*}{ 02/09/2011 } & Tinggi (cm) & 25.50 & 24.94 \\
\hline & & Lebar daun $(\mathrm{cm})$ & 17.66 & 18.14 \\
\hline \multirow[b]{2}{*}{5} & \multirow[b]{2}{*}{ 09/09/2011 } & Tinggi $(\mathrm{cm})$ & 39.09 & 38.45 \\
\hline & & Lebar daun (cm) & 18.50 & 19.39 \\
\hline \multirow{2}{*}{6} & \multirow{2}{*}{ 16/09/2011 } & Tinggi (cm) & 54.11 & 53.85 \\
\hline & & Lebar daun (cm) & 18.85 & 20.35 \\
\hline \multirow{2}{*}{7} & \multirow{2}{*}{ 23/09/2011 } & Tinggi (cm) & 69.58 & 66.88 \\
\hline & & Lebar daun (cm) & 20.14 & 20.48 \\
\hline
\end{tabular}

TENIA下 


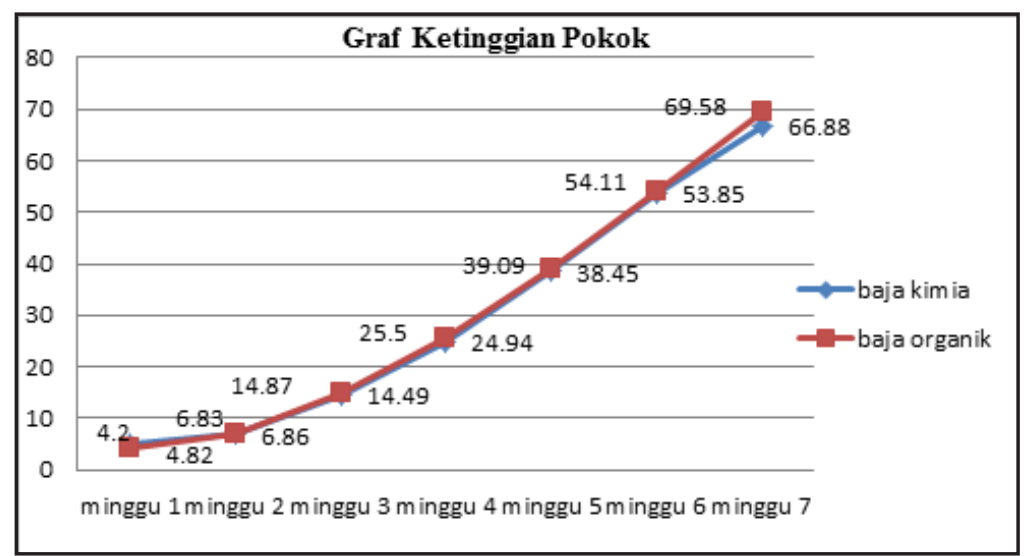

Rajah 5: Graf Ketinggian Pokok

Merujuk kepada Rajah 5 dapat dilihat tinggi pokok semasa tempoh kajian selama tujuh minggu. Berdasarkan kepada pengukuran data pada setiap minggu, didapati pokok sintetik telah mencapai ketinggian maksimum $66.88 \mathrm{~cm}$ pada minggu ke tujuh, dengan purata pertumbuhan setiap minggu adalah $8.86 \mathrm{~cm}$. Bagi pokok ujian yang menggunakan media cendawan yang tamat tempoh sebagai sumber nutrient pula, tinggi terakhir yang dicatatkan adalah $69.58 \mathrm{~cm}$. Berdasarkan pemantauan purata pertumbuhan pokok bendi yang menerima baja organik sebagai sumber nutrient purata pertumbuhan pada setiap minggu adalah sebanyak $9.34 \mathrm{~cm}$. Perbezaan yang tidak jauh beza di antara tinggi pokok ujian dengan pokok sentetik adalah $0.48 \mathrm{~cm}$ ini menunjukkan bahawa baja yang di hasilkan ini adalah setanding dengan baja kimia

Pada peringkat awal iaitu di dalam minggu pertama, kadar pertumbuhan keduadua pokok barisan tersebut telah menunjukkan perbezaan dimana baja sintetik telah mendahului baja kajian dengan purata $4.82 \mathrm{~cm}$ berbanding $4.2 \mathrm{~cm}$ bagi baja kajian. Ini kerana pemilihan anak pokok semasa diawal penanaman adalah diambil secara rawak.

Pada minggu kedua kadar pertumbuhan pokok bendi yang menerima sumber nutrient dari kimia mula perlahan, ini mungkin disebabkan pengaruh cuaca dan juga pengaruh klorin yang terdapat dalam air paip yang telah diserap oleh akar pokok, ini kerana menurut Marecos Do Monte (1988) kadar pertumbuhan pokok yang menerima air yang mempunyai klorin akan sedikit perlahan disebabkan rintangan pokok terhadap klorin.

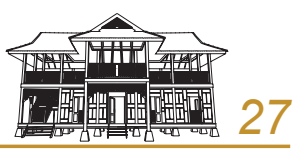


Setelah minggu ketiga pertumbuhan ketinggian pokok kajian mula menunjukan perubahan yang positif dengan purata $14.87 \mathrm{~cm}$ berbanding $14.49 \mathrm{~cm}$ bagi pokok sintetik. Ini kerana pada minggu ketiga ini baja yang terdapat pada media semaianya telah menyerap nutrient baru dan menunjukan kesan perubahanya.

Untuk minggu ke empat pula perbezaan kadar ketinggian untuk kedua - dua pokok tidak banyak perbezaan dengan purata 25.05 untuk baja kajian dan 24.94 untuk baja sintetik. Perbezaan antara kedua-duanya adalah 0.11 sahaja. Kadar pemberian baja adalah dua minggu sekali.

Sekitar minggu ke lima baja kajian meningkat dengan purata ketinggian yang memberangsangkan. Perbezaan purata diantara baja kajian dengan baja sintetik adalah $0.64 \mathrm{~cm}$. Pokok kajian mendahului pokok sintetik dengan purata ketinggian $13.59 \mathrm{~cm}$ berbanding $13.51 \mathrm{~cm}$. Ini terbukti baja kajian mampu menandingi baja sintetik dimasa hadapan jika kandungan nutrien di dalamnya ditambah.

Pada minggu ke enam pokok meningkat dengan purata $0.26 \mathrm{~cm}$ bagi kedua-dua pokok. Kadar ketinggian bagi pokok kajian adalah meninggkat dari $39.09 \mathrm{~cm}$ kepada $54.11 \mathrm{~cm}$. Manakala bagi pokok sintetik meningkat dari $38.45 \mathrm{~cm}$ kepada $53.85 \mathrm{~cm}$.

Peningkatan yang baik dari segi ketinggian, ini kerana pada minggu ke enam, pokok telah mendapat nutrien pemakanannya yang lengkap disamping itu aktiviti pengawalan baja daun,racun serangga dan racun kulat telah dilakukan terhadap pokok, untuk mengelak daripada jangkitan makluk perosak.

\subsubsection{Lebar Daun}

Dalam tempoh tujuh minggu daun pokok bendi terus meningkat pada setiap minggu. Bilangan daun pada setiap pokok juga bertambah mengikut umur pokok. Rajah 1 di atas dapat dilihat lebar daun pokok sentiasa meningkat dari minggu ke minggu. Didapati bilangannya semakin bertambah pada setiap minggu, pertumbuhan kelebaran daun bendi yang merima baja kimia lebih besar berbanding pokok bendi yang menggunakan baja dari media cendawan tetapi pokok yang menggunakan baja kimia mengalami pertumbuhan rumpai yang banyak dan mengalami kecacatan pada sesetengah daunnya berbanding pokok bendi yang menggunakan baja dari media cendawan walaupun saiz daunnya kecil tetapi pokoknya tidak mengalami sebarang masalah dan menujukan pertumbuhan yang baik. 


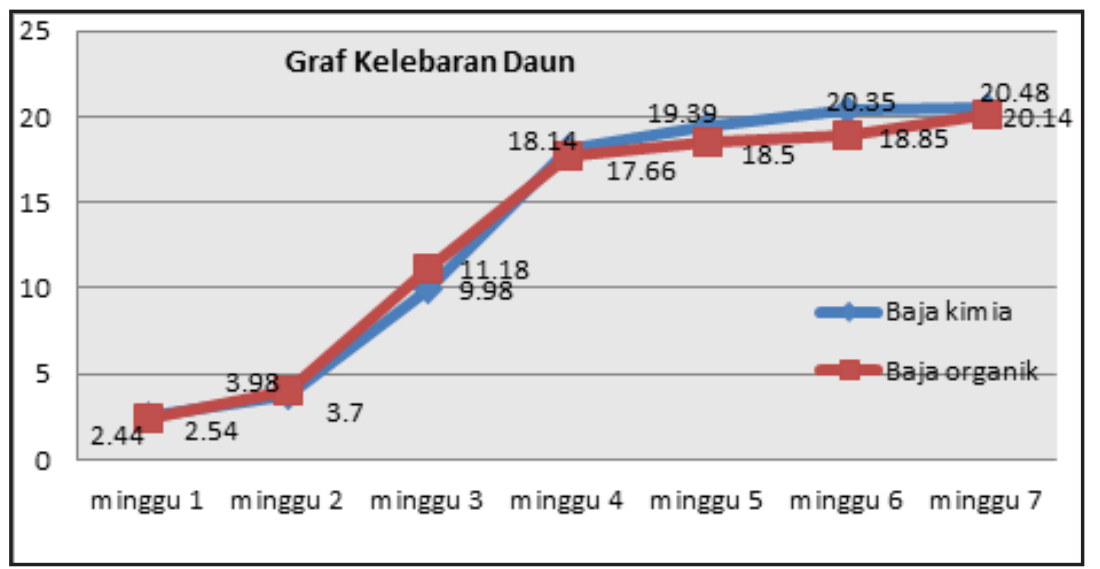

Rajah 6: Graf Kelebaran Daun

Seperti mana yang berlaku terhadap ketinggian pokok. Lebar daun juga didapati di pengaruhi oleh kandungan nutrient baja yang digunakan. Pokok yang menerima nutrient baja kimia mencatatkan kelebaran maksimum pada minggu tujuh sebanyak $20.48 \mathrm{~cm}$ Dengan purata pertumbuhan setiap setiap minggu adalah $17.94 \mathrm{~cm}$ (Rujuk Rajah 6).

Manakala bagi pokok yang menerima nutrient dari organik, ianya mencatatkan kelebaran daun yang berbeza dengan pokok yang menerima nutrient kimia iaitu dengan purata pertumbuhan setiap minggu adalah $17.7 \mathrm{~cm}$ bacaan kelebaran maksimum pada minggu ke tujuh adalah 20.14 $\mathrm{cm}$ dengan perbezaan $0.24 \mathrm{~cm}$. Keadaan ini mungkin disebabkan kandungan nutrient yang semakin merosot dalam nutrient efluen organik. 


\subsection{Kesimpulan}

Kajian yang telah dijalankan beberapa kesimpulan dapat dibuat. Didapati bahawa baja dari media cendawan tamat tempoh yang diproses semula berpotensi untuk digunakan bagi menggantikan penggunaan baja kimia ini. Walau bagaimanapun kajian yang lebih mendalam mengenai baja ini perlulah dilakukan pada masa akan datang. Pokok yang menerima baja media cendawan tamat tempoh ini menunjukkan pertumbuhan yang positif setiap minggu semasa kajian dijalankan. Baja dari media cendawan tamat tempoh yang telah digunakan dalam kajian ini dijangka dapat mengurangkan kesan pencemaran kepada sungai akibat penggunaan baja kimia.

Hasil daripada penggunaan baja dari media cendawan tamat tempoh untuk tanaman semasa kajian didapati ianya boleh digunakan. Melalui penggunaan ini ia akan dapat mengurangkan permintaan baja kimia dalam bidang pertanian. Selain itu ia juga akan mematuhi langkah-langkah-langkah dalam mengurangkan penggunaan baja kimia dalam pertanian yang sekian lama diketahui mengakibatkan pencemaran kepada tanah serta sumber air berdekatan kawasan pertanian.

Pemerhatian dari segi fizikal tumbuhan yang menggunakan baja dari media cendawan ini menunjukkan kesan yang positif apabila tumbuhan menunjukkan peningkatan tumbesaran pada minggu ke tiga hingga minggu yang ke tujuh jika dibandingkan dengan tumbuhan yang menggunakan baja kimia. Ini membuktikan kandungan nutrien yang diperlukan dalam tumbuhan tersebut mempengaruhi kadar pertumbuhan tanaman. 


\section{Rujukan}

Jabatan Pertanian Malaysia (2006), "Panduan menanam bendi", Malaysia, http://pertanianmjg.perak.gov. my/bahasa/panduan.htm

Malaysian Agricultural Research And Devolepment Institute (2002), "Teknik Pengukuran Pertumbuhan Pokok". Malaysia.

Nurliyana Mohd Norani (2007), “Kesan Penggunaan Baja Tahi Ayam Ke atas Penghasilan Kacang Bendi”. Tesis Sarjana Muda, Universiti Malaysia Sabah.

Redzuan Mohd Razalan (2006), "Kajian Guna Semula Efluen Terolah Kolam Pengosidaan Terhadap Tanaman Hidroponik (Citrullus Lunatus)", Tesis Sarjana Muda Kejuruteraan Awam Universiti Teknologi Malaysia.

Tarmizi Osman (2005), "Kajian Potensi Guna Semula Efluen Terhadap Tanaman Hidroponik (Cucumis Sativus)", Tesis Sarjana Muda Kejuruteraan Awam, Universiti Teknologi Malaysia. 
